\title{
TELAAH KRITIS TERHADAP ARGUMEN MAYORITAS ULAMA TENTANG NASAB ANAK ZINA
}

\author{
Muhammad \\ Universitas Islam Negeri Maulana Malik Ibrahim Malang, \\ Indonesia \\ E-mail:muhammadlc@syariah.uin-malang.ac.id
}

\begin{abstract}
The lineage of the children of adultery as agreed by religious scholars ('ulamā) and Indonesian Ulama Council (MUI) is ascribed to the mother, not the father. This is due to the unclarity of the marital bond between the woman and the man who conduct adultery, and due to the uncertainty of sperms that fertilize the ovum (egg cell) of a woman. Consequently, the children of adultery become exiled and marginalized in society, bearing mistakes of their 'parents'. In fact, Islam has emphasized that every child born is essentially chaste. If the child born from adultery is ascribed to the mother, he/she does not have whatever rights from the father. Therefore, it is important to review the question regarding the lineage of the children of adultery, in order to determine the future of the children. Based on the literature research with critical analysis method, this article argues that the children of adultery remain to be biologically ascribed to the father together with their rights from the latter. The children born from adultery do not bear the mistakes of their 'parents.' In the contemporary era, to determine the children lineage can use such a tool as DNA test that is believed as accurate.
\end{abstract}

Keywords: Children of adultery; biological father; critical analysis.

\section{Pendahuluan}

Persoalan nasab menjadi salah satu tema penelitian yang selalu menarik antusiasme para pengkaji ajaran agama Islam, sebab ia memiliki hubungan yang erat dengan perwalian, nafkah, peng- 
asuhan anak (hadānah), waris, dan muharramāt al-nikāạ. ${ }^{1}$ Selain itu, status nasab juga dapat menjadi penunjang terhadap kemuliaan seseorang. ${ }^{2}$ Karena nasab merupakan hal yang urgen, al-Qur'ān memberikan penjelasan dan mengulangi lafal "al-nasab" sebanyak dua kali, yaitu dalam surat al-Furqān [25]: 54 dan al-Ṣāffāt [37]: 158. ${ }^{3}$ Lebih dari itu, nasab sendiri menjadi salah satu kaidah kullyyah dalam hukum Islam yang berupa hif za al-nasab, yang dengannya dapat memperkuat komponen sosial, terwujudnya kasih sayang, dan terbinanya hubungan antarsesama manusia. ${ }^{4}$

Mengenai status penetapan nasab, para ulama sepakat bahwa pernikahan yang sah menjadi salah satu sebab munculnya hubungan nasab. Dengan kata lain, seorang anak yang terlahir dari perkawinan secara sah otomatis memiliki hubungan nasab dengan bapak biologisnya. ${ }^{5}$ Bagi setiap orang tua, dilarang untuk tidak mengakui anak yang terlahir dengan ikatan yang sah sebagaimana dijelaskan dalam sabda Nabi riwayat Abū Hurayrah:

Siapa saja dari wanita yang masuk dalam kelompok orang lain, padahal ia bukan golongannya, maka Allah tidak akan memasukkan ke dalam surga-Nya; dan siapa saja dari lelaki yang mengingkari anaknya sedangkan ia tahu bahwa itu adalah anaknya, maka Allah akan menutupi aib anak itu dan membuka aib laki-laki itu pada hari kiamat kelak. ${ }^{6}$

Dewasa ini, banyak terjadi kasus lahirnya bayi yang dihasilkan dari hubungan intim antara laki-laki dan perempuan tanpa adanya ikatan pernikahan yang sah (anak zina), baik dari kacamata sharīah

\footnotetext{
1 Moh. Dliya'ul Chaq, "Nasab Anak dalam Hukum Islam; Membaca Peluang Sains dan Teknologi dalam Penetapan Nasab", Tafáqqub: Jurnal Penelitian dan Kajian Keislaman, Vol. 6, No. 1 (2018), 61.

${ }^{2}$ La'lī Khadijah, al-Turq al-Shar'ìyah li Ithbät al-Nasb fi al-Fiqh al-Islämì wa al-Tashri al-Jazāirì (Tesis--Jāmi'ah Muhammad Khayḍir, 2015), 59.

${ }^{3}$ Selain dua ayat tersebut, terdapat satu ayat lain yang menggunakan akar kata nasab, yaitu dalam al-Mu'minūn [23]: 10. Namun, yang disebut terakhir ini berkaitan dengan kisah hari akhir, sehingga penulis tidak memasukkannya ke dalam pembahasan nasab.

4 Maḥmūd 'Alī al-Sarțawī, Fiqh al-Aḥwāl al-Shakhșīyah (al-Zawāj wa al-Ṭalāq) (Beirut: Dār al-Fikr, 2008), 210.

5 'Abd al-Wahhāb Aḥmad Muḥammad al-Sa'îdī, "Ithbāt al-Nasb wa Nafyuh fì al-Islām: Dirāsah fī al-Murtakiz al-Ușūlī wa al-Munjiz al-Fiqhî̀”, Jami 'ah al-Nāssr, Vol. 2, No. 4 (2014), 316.

${ }^{6}$ Aḥmad b. Shu'ayb al-Nasā̄̄è, al-Sunan al-Kubrā, Vol. 5 (Beirut: Muassasat alRisālah, 2001), 286.
} 
maupun hukum positif negara. Kasus ini penting untuk dicermati ulang, khususnya dalam sudut pandang agama Islam, sebab ia berhubungan dengan masa depan, martabat sosial, dan nasib anak atau bayi yang bersangkutan. Jika pendapat para ulama fiqh yang ada selama ini, termasuk pula artikel-artikel yang bertebaran di jurnal-jurnal akademik Indonesia, fatwa Majelis Ulama Indonesia (MUI) No, 11 Tahun 2012, Peraturan Kompilasi Hukum Islam Pasal 100 Bab XIV (KHI), dan Putusan Mahkamah Konstitusi (MK) No 46/PUU-VIII/2010 yang cenderung merugikan anak zina, serta-merta dibenarkan tanpa evaluasi lebih jauh, maka nasib anak zina di negeri ini akan sangat memprihatinkan.

Pada dasarnya, putusan fatwa MUI telah memberikan rekomendasi berupa perlindungan dan kemudahan bagi anak zina. Namun, hal tersebut tidaklah cukup ,bahkan berpotensi untuk tidak berjalan secara efisien, mengingat yang memberikan respons (terhadap keberadaan anak zina) adalah masyarakat lokal tertentu yang belum tentu terjangkau oleh pemerintah. Kondisi tersebut pada gilirannya dapat mempengaruhi kondisi psikologis seorang anak zina, terutama ia yang mulai tumbuh dan berbaur dengan masyarakat, bahkan memprngaruhi pertaruhan untuk kesuksesannya di masa depan. Oleh karena itu, dalam rangka mengkaji ulang tentang nasab anak zina dalam perspektif hukum Islam, artikel ini mencoba membuka wawasan baru tentang upaya penetapan hubungan nasab anak zina.

Meskipun perkara nasab anak zina sejatinya telah menjadi kajian yang intens dalam dunia akademik, tetapi diakui atau tidak, beberapa penelitian yang ada masih sampai pada kesimpulan bahwa anak zina bernasab pada sang ibu, dan tidak bisa melanjutkan nasab kepada sang bapak biologis. Sebagai contoh, Fahmi Al Amruzi dalam penelitiannya membagi dua jenis anak yang lahir di luar nikah, yaitu (1) anak yang terlahir dengan cara wat' shubhah atau nikah shubhat, nasabnya kembali pada bapak; dan (2) anak yang lahir karena perzinaan, yang nasabnya adalah pada ibu, bukan pada bapaknya. ${ }^{7}$ Agus Mustaghfir juga memberikan kesimpulan bahwa anak zina tidak bisa dinasabkan kepada bapak

\footnotetext{
${ }^{7}$ Fahmi Al Amruzi, "Hak dan Status Anak Syubhat dalam Pernikahan", Syariah: Jurnal Hukum dan Pemikiran, Vol. 17, No. 1 (2017), 1.
} 
biologisnya, bahkan tidak memiliki status hubungan apapun. ${ }^{8}$ Demikian pula hasil penelitian Moh. Dliya'ul Chaq, yang menjelaskan bahwa "dalam kondisi wanita zina yang tidak dalam ikatan perkawinan, ketentuan umum tentang anak zina berlaku. Artinya, bahwa anak tersebut hanya bernasab pada ibunya, baik ada laki-laki yang mengakui perzinaannya atau tidak ada". ' Selain beberapa hasil penelitian yang telah dipaparkan di atas, terdapat beberapa penelitian lainnya yang lebih awal, tetapi semuanya berakhir pada satu kesimpulan: anak zina bernasab kepada ibunya.

Penelitian-penelitian terdahulu tampak lebih banyak bersandar pada argumen ulama fiqh yang menyatakan bahwa anak zina bernasab kepada ibu, tanpa mengoreksi ulang argumen-argumen tersebut yang terbilang belum dapat dipertanggungjawabkan sepenuhnya. Selain itu, argumen ini terkesan diskriminatif terhadap anak zina, yang pada dasarnya tidak melakukan kesahalan apapun tetapi harus menanggung kesalahan yang diperbuat oleh orang tuanya. Oleh karena itu, kajian ulang tentang nasab anak zina perspektif hukum fiqh ini diharapkan dapat menjadi sumbangsih terhadap putusan MK, peraturan KHI, dan fatwa MUI. Selain itu, kajian ini sangat mempertimbangkan lima pernyataan dalam alQur'ān yang menjelaskan bahwa kesalahan seseorang tidak dapat dilimpahkan pada orang lain, yaitu dalam al-Isrā' [17]: 15, al-An'ām [6]: 164, al-Zumar [39]: 7, al-Najm [53]: 38, dan Fātị [35]: 18.

\section{Ragam Nasab Anak pada Bapak tanpa Akad Nikah yang Sah}

Terdapat dua kasus penetapan nasab anak pada bapak walau tanpa didasari oleh ikatan pernikahan yang sah, sebagaimana telah disepakati oleh ulama fiqh. Pemaparan dua model kasus ini amatlah penting, karena keduanya bisa menjadi preseden dalam penetapan nasab anak zina kepada bapak biologisnya. Pertama, nikāh fäsid, yaitu pernikahan yang terdapat kecacatan baik dari segi rukun atau syaratnya. Nikeăh fäsid terbagi dua, yaitu (1) pernikahan yang disepakati kecacatannya dan berlaku untuk selamanya serta hukumnya tidak akan pernah berubah, seperti halnya menikah dengan orang yang diharamkan sebab nasab, sepersusuan, atau ikatan kekeluargaan sebab pernikahan (musāharah); (2) pernikahan

\footnotetext{
8 Agus Mustaghfir, "Kewarisan Anak Zina dalam Tinjauan Hukum Islam dan KUH Perdata” (Tesis--IAIN Ponorogo, 2018), 89.

${ }_{9}$ Chaq, "Nasab Anak dalam Hukum Islam", 69.
} 
yang masih terjadi kontroversi terhadap kecacatannya, yakni kecacatan pernikahan tersebut hanya berjalan dalam sementara waktu. Ketika 'illah atau pencegahnya hilang, maka nikahnya dapat dihukumi sah.

Ketika telah terjadi akad nikah dengan cara ini, maka pernikahannya tidak dapat disahkan dan tidak memiliki efek terhadap segala implikasi atau kewajiban pernikahan. Jika seseorang yang melakukan akad nikeăh fäsid tersebut bersenggama dengan pasangannya, sedangkan ia tidak tahu bahwa nikahnya fäsid, maka orang tersebut tetap memiliki ikatan sebagaimana pernikahan yang sah pada umumnya, seperti memiliki hubungan musāharah, ketetapan nasab dengan anak yang dilahirkan, dan kewajiban membayar mahar. ${ }^{10}$ Namun, bila ia mengetahui ke-fäsid-an nikahnya, maka ia dikenai hadd. ${ }^{11}$

Kedua, wati' shubhah. Ulama mendefinisikan wati' shubhab sebagai sebuah hubungan intim antara laki-laki dengan perempuan yang tetapi bukan zina walaupun tanpa adanya akad pernikahan yang sah. Misalnya, seorang laki-laki menyenggamainya seorang perempuan yang menginap di rumahnya, tanpa mengetahui bahwa perempuan tersebut bukanlah istrinya. ${ }^{12}$ Ketika terjadi wati' shubbah, kemudian sang perempuan hamil dan melahirkan, maka anak yang terlahir tersebut tetap bernasabkan pada laki-laki yang me-watinya. ${ }^{13}$

Anak yang terlahir dari seorang perempuan yang hamil dalam konteks kedua model kasus di atas, tetap bernasabkan kepada lakilaki yang menyenggamainya, meski pada dasarnya dua model kasus tersebut terjadi tanpa adanya ikatan pernikahan yang disahkan menurut sharíah Islam. Hal yang menarik adalah ketika para ulama menetapkan nasab sang anak pada laki-laki yang bersenggama tersebut dengan alasan anak tersebut terlahir jelas dari sperma lakilaki yang bersangkutan. Pada titik ini, bila yang menjadi penekanan

\footnotetext{
10 Ibrāhīm b. Mūsā b. Muḥammad al-Shātịī, Uṣūl al-Fiqh wa al-Qawāí id alFiqhìyah, Vol. 4 (Beirut: Dār Ibnn 'Affān, 1997), 204.

11 Aḥmad b. Idrīs al-Qarāfì, al-Furūq, Vol. 4 (Mesir: Dār al-Salām, 2001), 1307.

12 Wahbah al-Zuhaylī, al-Figh al-Islāmi wa Adillatuh, Vol. 7 (Beirut: Dār al-Fikr, 1984), 88.

13 Zakariyyā al-Anșārī, Asnā al-Matālib fì Sharh Rawd al-Ṭälib, Vol. 3 (Beirūt: Dār al-'Ilmīyah, 2000), 185; lihat juga Ibrāhīm b. 'Alī b. Yūsuf al-Shayrāzī, alMubadhdhab fì Fiqh al-Imām al-Shäfít, Vol. 2 (Beirut: Dār al-Fikr, t.th.), 145.
} 
adalah persoalan jelas-tidaknya sperma laki-laki, maka hal ini tentu juga dapat dijadikan landasan bagi kasus perzinaan; ketika laki-laki dan perempuan berzina, dan perempuannya hamil, maka jelas yang terlahir adalah hasil sperma laki-laki yang bersangkutan, sehingga anak tersebut dapat dinasabkan padanya.

\section{Penetapan Nasab dalam Metode Klasik dan Modern}

Pada dasarnya, nasab seorang anak dinisbahkan pada ibunya, ketika tidak ada satupun laki-laki yang mengakui anak tersebut berasal dari spermanya, pun tidak terdapat hubungan persenggamaan. Hamil menjadi bukti kelahiran seorang anak dari rahim sang ibu, sebagaimana yang dijelaskan oleh para ulama seperti al-Sarakhasī, ${ }^{14}$ al-Jawzi ${ }^{15}$ Ibn Rushd, ${ }^{16}$ dan lainnya. Namun, ketika ada satu lakilaki yang mengakui bahwa anak yang terlahir adalah anak biologisnya, maka nasab anak tersebut kembali kepada bapaknya atau laki-laki yang bersangkutan. ${ }^{17}$

Jika ditelurusi secara menyelurh, maka dapat dipetakan metode-metode penentuan nasab, yang bisa dibedakan antara metode yang berlaku pada masa klasik dan pada masa modern. Di antara metode penetapan nasab masa klasik yaitu: pertama, al-haml. Kehamilan dapat menjadi bukti hubungan nasab seorang anak kepada bapaknya dengan dua perkara, yaitu (1) seorang suami harus memiliki keperkasaan yang dapat ditandai dengan cara baligh atau pubertas, dan (2) seorang suami bukan tergolong orang yang impoten. ${ }^{18}$ Bila dua hal ini tidak dipenuhi, maka nasab anak yang lahir dinasabkan pada ibunya. Kedua, al-iqrär bi al-nasab, yaitu ikrarnya seseorang dengan penuh kesadaran dan tanpa paksaan bahwa dirinya memiliki ikatan persaudaraan dengan orang lain. ${ }^{19}$

\footnotetext{
${ }_{14}$ Muhammad b. Aḥmad b. Abī Sahl al-Sarakhsī, al-Mabsūt li al-Sarakhsī, Vol. 8 (Beirut: Dār al-Ma'rifah, 1993), 87.

15 Muḥammad b. Abī Bakr al-Jawzī, Jalā’ al-Afhām fì Fadl al-Ṣalāḥ 'alā Muḥammad Khayr al-Anām, Vol. (Bairut: Dār al-Ma'rifah, 1987), 226.

${ }^{16}$ Muhammad b. Ahmad b. Rushd, al-Bayān wa al-Tahsill wa al-Sharh wa al-Tawjīh wa al-Ta'lìl li Masāill al-Mustakhrajah, Vol. 14 (Beirut: Dār al-Gharb al-Islāmī, 1988), 279.

17 Al-Jawzì, Jalä’ al-Afhàm, Vol. 1, 226.

18 'Abd al-Qādir Dawādī, Aḥām al-Usrah bayn al-Fịh al-Islāmì wa Qānūn al-Usrah al-jaz̧āìì (Beirut: Dār al-Bașā’ir, 2010), 191.

${ }_{19}$ Aḥmad Muṣtafā Shalabī, Aḅkām al-Usrah fì al-Islām: Dirāsah Muqāranah bayn alMadhābib al-Sunnìah wa al-Madhāhib al-Ja'farìyah wa al-Qānūn (Beirut: Dār alNahḍah al-'Arabìyah li al-Nashr, 1977), 645.
} 
Dengan adanya ikrar, maka seseorang yang menjadi objek ikrar secara otomatis memiliki hubungan nasab dengan segala konsekuensinya. ${ }^{20}$ Ketiga, al-firäsh (perempuan yang dimiliki). ${ }^{21}$ Ketika seorang perempuan dimiliki oleh seorang laki-laki, baik perempuan tersebut merdeka ataupun budak, maka anak yang terlahir darinya bernasabkan pada laki-laki (pemilik firäsh) tersebut. Keempat, al-qiyäfah, yaitu menetapkan nasab berdasarkan kemiripan antara anak dengan bapaknya. ${ }^{22}$ Konsep penetapan nasab dengan cara ini sering kali dilakukan oleh Nabi ketika terjadi sengketa antara dua orang yang saling mengakui anak atau bayi yang terlahir dari seorang perempuan. Hal ini sering kali disinggung dalam Hadīth, yang salah satunya diriwayatkan oleh 'Ā'ishah:

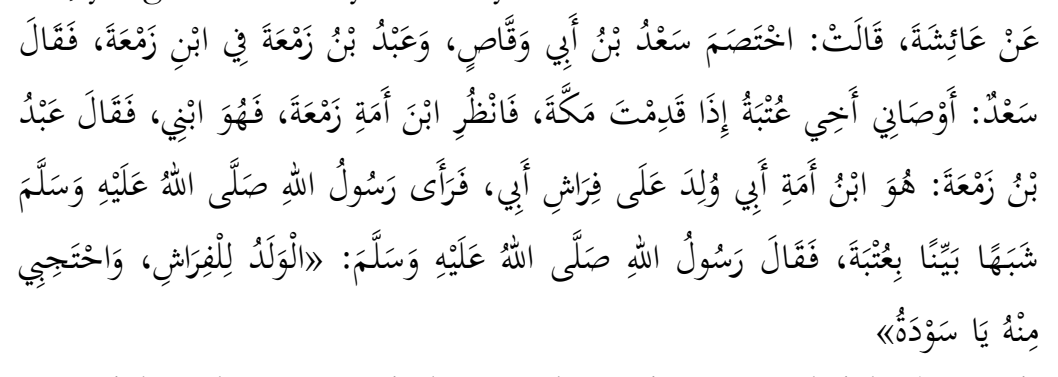

"Sa'ad b. Abī Waqqāsh bersengketa dengan 'Abd b. Zam'ah mengenai seorang anak laki-laki. Sa'ad berkata: "Utbah telah berpesan kepadaku bahwa ini memang anaknya, lihatlah kemiripannya (dengan saudaraku). 'Abd b. Zam'ah berkata: 'Anak ini adalah saudaraku, karena dia dilahirkan di ranjang ayahku dari budak perempuan ayahku'. Kemudian Nabi memperhatikan kemiripannya, ternyata dia persis seperti

\footnotetext{
20 Aḥmad Farāj Husayn, Aḅkēm al-Usrah fì al-Isläm, al-Talāq wa Huqūq al-Awlàd wa Nafaqāt al-Aqārib (Beirut: Dār al-Jāmi'ah li al-Nashr, 1998), 260.

${ }^{21}$ Lafaz al-firāsh memiliki arti istri dari seorang lelaki. Muhammad b. Muhammad b. 'Abd al-Razzāq al-Zubaydī, Täj al-'Arūs min Jawāhir al-Qāmūs, Vol. 17 (Kuwait: Dār al-Hidāyah, 2004), 305; Ibn Fāris mengartikannya dengan perempuan, sebab perempuan adalah pihak yang disenggamai. Aḥmad b. Fāris al-Qaswaynī, Mújam Maqāyiss al-Lughah, Vol. 4 (Beirut: Dār al-Kutub al-'Ilmīyah, 1979), 486; sementara Abū Hanīfah mengartikan lafaz tersebut sebuah nama untuk pasangan suami-istri, dalam Muḥammad b. 'Alī b. Muḥammad al-Shawkānī, Nayl al-Awtār min Aḅädìth Sayyid al-Akhbār, Vol. 6 (Mesir: Idārah al-Ṭaba'ah alMunīrīyah, t.th.), 331.

22 Muḥy al-Dīn b. Sharf al-Nawawī, al-Majmū' Sharḥ al-Muhadhdhab, Vol. 15 (Beirut: Dār al-Fikr, t.th.), 307.
} 
'Utbah. Lalu Nabi bersabda: 'Ini adalah milikmu, wahai 'Abd, yaitu untuk orang yang punya ranjang di mana anak tersebut dilahirkan. Karena itu, tetaplah kamu menutupkan tabirmu terhadapnya wahai Sawdah b. Zam'ah"”.

Kelima, al-qur'ah, yaitu penetapan nasab melaui undian, dan metode ini adalah yang paling lemah. ${ }^{23}$ Terkait penetapan nasab dengan metode ini, terjadi perbedaan di kalangan para ulama yang terbagi ke dalam dua kelompok: (1) kelompok yang menggunakan konsep undian seperti halnya al-Shāficìah,, ${ }^{24}$ al-Hanābilah, ${ }^{25}$ alZāhirīyah, dan al-Mālikīyah, dan (2) kelompok yang mengingkari metode ini, al-Hanafiyah. ${ }^{26}$

Sementara itu, pada masa modern telah ditemukan metode yang berfungsi untuk mendeteksi semua informasi biologis dari setiap makhluk hidup. Metode ini dikenal dengan sebutan tes DNA (Deoxyribonucleid Acid), sejenis biomolekul yang menyimpan dan menyandi instruksi-instruksi genetika setiap organisme dan banyak jenis virus. Menurut Rina Budi Satiyarti:

DNA adalah dasar kimiawi hereditas dan penyusun gen yang menjadi unit fundamental informasi genetik. Informasi genetik yang disimpan dalam nukleotida berfungsi untuk memenuhi dua tujuan, yaitu sumber informasi bagi sintesis semua molekul protein pada sel serta organisme, dan memberikan informasi yang diwariskan kepada anak atau generasi berikutnya. ${ }^{27}$

Mayoritas ulama kontemporer berargumen bahwa DNA dapat menjadi alat pembuktian nasab. ${ }^{28}$ Meskipun demikian, para ulama melegalkan DNA sebagai alat pendeteksi nasab dalam kondisi tertentu saja, yaitu (1) ketika terjadi sengketa penetapan nasab terhadap anak yang tidak diketahui nasabnya; (2) ketika terjadi percampuran anak saat di rumah sakit atau lokasi penitipan anak

\footnotetext{
${ }^{23} \mathrm{Al}-\mathrm{Sa}$ 'īdī, "Ithbāt al-Nasb wa Nafyuh", 305.

${ }^{24}$ Al-Sarakhsī, al-Mabsüt, Vol. 16, 149.

25 'Abd Allāh b. Aḥmad b. Qudāmah, al-Mughnì li Ibn Qudāmah, Vol. 6 (Beirut: Dār al-Fikr, 1405), 45.

${ }^{26}$ Muḥammad al-Khaṭīb al-Sharbīnī, Mughnì al-Muḥtāj ilā Ma'rifat Ma'ānì Alfäz̆ alMinhājj, Vol. 4 (Beirut: Dār al-Fikr, t.th.), 488.

${ }^{27}$ Rina Budi Satiyarti et al., "Identifikasi Fragmen DNA Mitokondria pada Satu Garis Keturunan Ibu dari Sel Epitel Rongga Mulut dan Sel Folikel Akar Rambut", Biosfer, Vol. 8, No. 1 (2017), 17.

28 Awān 'Abd Allāh al-Fayḍī, "Suit for DNA Correction Comparative Study in Judicial Evidence”, Route Education and Social Science, Vol. 5, No. 6 (2018), 147.
} 
sehingga sulit untuk dideteksi mana anak yang bernasab pada orang tententu; dan (3) di saat kehilangan anak baik disebabkan munculnya musibah, peperangan, dan lainnya yang mengakibatkan seseorang kesulitan mengenali keluarganya. ${ }^{29}$

\section{Nasab Anak Zina pada Bapak}

Pada dasarnya, penetapan nasab anak zina masuk dalam ranah ijtihädìyah, karena tidak ada satupun landasan dari nas yang secara tekstual membincang masalah nasab anak zina. Hadìth Nabi yang diriwayatkan Abū Hurayrah yang menjadi salah satu landasan munculnya argumen anak zina bernasab kepada ibu masih menjadi kontroversi dalam penafsirannya. Bahkan, pendapat ulama yang menyatakan bahwa anak zina bernasab kepada bapaknya juga berlandaskan pada riwayat tersebut, sehingga tidak heran bila masih terjadi perbedaan pendapat antara ulama fiqh dalam masalah penetapan nasab anak zina. Walau demikian, yang membutuhkan perhatian lebih adalah men-tarjị kontroversi antarulama fiqh, sehingga menghasilkan produk fatwa yang lebih relevan dan lebih akurat, serta meninjau ulang nasib anak zina bila ia dianggap anak yang tidak memiliki bapak.

Bila dirunut kembali, terdapat tiga pendapat perihal status nasab anak hasil zina, yaitu (1) tidak memiliki hubungan nasab dan tidak dapat dinasabkan pada bapaknya, sebagaimana pendapat mayoritas ulama fiqh dari golongan Hanafìyah, Mālikīyah, Shāfíīyah, Hanābilah, dan Zāhirīyah; ${ }^{30}$ (2) anak zina dapat memiliki nasab dan dapat dinasabkan pada bapaknya jika sang bapak mengakuinya, ${ }^{31}$ demikian pendapat dari Sulaymān b. Yasār, Ishạāq b. Rāhawayh, dan 'Urwah b. Zubayr; (3) nasab anak zina dapat ditetapkan pada bapak biologisnya dan harus dilaksanakan

\footnotetext{
${ }^{29}$ Samiyah Buhāāah, "Ishkālāt Ithbāt al-Nasb bi al-Ṭarq al-'Ilmīyah al-Hadīthah (al-Bașmah al-Warāthīyah)", al-Dirāsāt wa al-Bubūth al-Qānūnìyah, Vol. 1, No. 1 (2016), 221.

30 Al-Sarakhsī, al-Mabsūt, Vol. 17, 279; lihat pula Zakariyyā al-Anșārī, Asnā alMatālib, Vol. 2, 319; 'Alī b. Muḥammad b. Hazm, al-Muhallā, Vol. 9 (Beirut: Dār al-Fikr, t.th.), 302.

31 'Abd Allāh b. Aḥmad b. Qudāmah, al-Mughnā fì Fiqh al-Imām A hmad b. Hanbal, Vol. 7 (Beirut: Dār al-Fikr, 1405), 130; lihat juga Ahmad b. 'Abd al-Halīm b. Taymìyah, al-Fatāwà al-Kubrā, Vol. 3 (Beirut: Dār al-Kutub al-'Ilmīyah, 1987), 187.
} 
hukuman pada sang bapak (had), ${ }^{32}$ demikian pendapat dari Hasan al-Bașrī, Ibn Sìrīn, dan Ibrāhīm al-Nakha'̄î.

Dari tiga pendapat di atas, dapat diprediksi bahwa hasil fatwa MUI sebatas mengutip pendapat mayoritas ulama, ${ }^{33}$ tanpa meneliti ulang pendapat yang berbeda. Padahal, bila dikaji secara seksama, pendapat kedua lebih kuat dan unggul dari pada pendapat pertama. Hal ini selaras dengan hasil penelitian yang dilakukan oleh Doucoure Abdou Samad dan Muneer Ali Abdul Rab, yang menyatakan:

Secara prinsip, maqüsid al-sharíah tidak membenarkan adanya seorang anak dalam kehidupan sosial tanpa adanya bapak. Oleh karena itu, dalam kasus anak zina, dibutuhkan tindak lanjut untuk segera menemukan bapaknya (jika tidak ada yang mengaku sebagai bapak biologisnya). Metode yang dapat dijadikan sebagai alat bukti untuk menemukan bapaknya pada masa sekarang adalah DNA. ${ }^{34}$

Mengenai akurasi tes DNA, Iftitah Utami menjelaskan, "tes DNA dalam konteks hukum Islam dapat dijadikan alat bukti yang sah, karena tes DNA juga tidak terlepas dari masqāsid al-sharí ab" ${ }^{35}$

Sementara itu, terdapat beberapa landasan untuk memperkuat pandangan bahwa anak hasil zina bernasabkan pada bapak biologisnya, baik landasan yang berdasarkan Hadīth, Athar, Qiyas, maupun logika, sebagaimana akan dirinci di bawah ini.

Pertama, Hadīth. Hadìth yang diriwatkan oleh Ibn Mājah, ${ }^{36}$ alBayhaq $\overline{1},{ }^{37}$ al-Baghawi ${ }^{38}$ Aḥmad b. Hanbal, ${ }^{39}$ dan para muhaddith lainnya, mencantumkan riwayat dari ' $\overline{\mathrm{A}}$ ' ishah ini:

\footnotetext{
32 Ibn Qudāmah, al-Mughni, Vol. 7, 130. Lihat juga Ibn Taymīyah, Majmū‘ alFatāwā, Vol. 32 (Beirut: Dār al-Wifā', 2005), 137.

${ }^{33}$ Fatwa Majelis Ulama Indonesia No. 11 Tahun 2012 tentang Kedudukan Anak Hasil Zina dan Perlakuan Terhadapnya, 10.

34 Doucoure Abdou Samad dan Muneer Ali Abdul Rab al-Quibaty, "Nasb Walad al-Zinā: Dirāsah Fiqhīyah fī Daw' Maqșud Hif̣̆ al-Nasl”, al- Ulūm alIslämìyah al-Dawlìah, Vol. 1, No. 2 (2017), 136.

35 Ifititah Utami, "Eksistensi Tes Deoxyribo Nucleic Acid dalam Menentukan Nasab”, Medina-Te, Vol. 14, No. 2 (2016), 158.

${ }^{36}$ Muḥammad b. Yazīd b. Mājah, Sunan Ibn Mājah, Vol. 3 (Beirut: Dār al-Risālah al-'Ālamìyah, 2009), 169.

${ }^{37}$ Aḥmad b. al-Husayn al-Bayhaqī, al-Sunan al-Kubrā, Vol. 6 (Beirut: Dār al-Kutub al-'Ilmìyah, 2003), 142. Lihat juga al-Bayhaqī, Ma'rifah al-Sunan wa al-Äthār, Vol. 8 (Mesir: Dār al-Wifā', 1991), 297.
} 


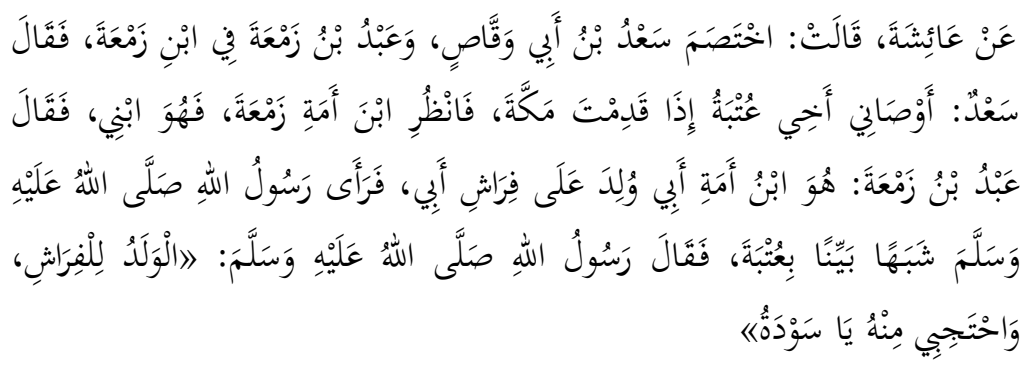

"Sa'd b. Abī Waqqāṣ bersengketa dengan 'Abd b. Zam'ah mengenai seorang anak laki-laki, Sa'ad berkata: 'Wahai Rasulullah, ini adalah anak dari saudaraku, 'Utbah b. Abī Waqqāṣ, dia telah berpesan kepadaku bahwa ini memang anaknya, lihatlah kemiripannya (dengan saudaraku)'. 'Abd b. Zam'ah berkata: 'Wahai Rasulullah, anak ini adalah saudaraku, karena dia dilahirkan di ranjang ayahku dari budak perempuan ayahku'. Kemudian Rasulullah memperhatikan kemiripannya, ternyata ia persis seperti 'Utbah, lalu beliau bersabda: 'Ini adalah milikmu, wahai 'Abd, orang yang punya ranjang, di mana anak tersebut dilahirkan. Sedangkan laki-laki yang menzinai ibunya tidak memiliki hak apa-apa terhadapnya. Karena itu, tetaplah kamu menutupkan tabirmu terhadapnya wahai Sawdah b. Zam'ah"”.

Pada riwayat Hadīth di atas, yang dimaksud dengan al-walad li al-firäsh ialah ketetapan nasab anak terhadap orang yang menghamili seorang perempuan walau di luar ikatan nikah. Ketetapan nasab anak di luar nikah ini merupakan intisari dari adanya pertikaian antara dua sahabat Nabi, yaitu Sa'd b. Abì Waqqāṣ dan 'Abd Allāh b. Zam'ah yang saling mengakui anak yang dilahirkan dari seorang perempuan. Secara logika, tidak mungkin terjadi pertikaian atau perebutan anak bila dilandasi dengan ikatan pernikahan. Namun, pada kenyataannya, perebutan yang terjadi di antara dua sahabat tersebut mengindikasikan bahwa anak yang dimaksud adalah hasil dari hubungan di luar nikah.

Ibn Taymīyah menafsirkan riwayat tersebut dengan menyatakan bahwa "Nabi Muhammad menghukumi secara tersurat,

38 Al-Husayn b. Mas'ūd al-Baghawī, Sharh al-Sunnah, Vol. 9 (Beirut: al-Maktab alIslāmī, 1983), 275.

${ }^{39}$ Aḥmad b. Muḥammad b. Hanbal, Musnad al-Imām Ạ̣mad b. Hanbal, Vol. 41 (Beirut: Muassasat al-Risālah, 2001), 442. 
sehingga menetapkan nasab anak tersebut pada 'Abd Allāh b. Zam'ah yang telah menggauli perempuan tersebut pada masa jahiliyah. Secara tersirat, perempuan yang hamil kemudian melahirkan seorang anak, maka anak tersebut bernasabkan pada lelaki yang menghamili ibunya". ${ }^{40}$ Lebih lanjut, 'İsā Amīzah menjelaskan, pada konteks riwayat di atas, Nabi membenarkan pengakuan 'Abd Allāh b. Zam'ah setelah melihat adanya kemiripan wajah antara Ibn Zam'ah dan anak tersebut. Adanya kemiripan dapat menjadi bukti bahwa anak tersebut adalah anak biologisnya". ${ }^{41}$ Selain itu, Asriyati dalam penelitiannya mengenai riwayat di atas menjelaskan bahwa al-walad li al-firäsh dapat menjadi solusi bagi wanita hamil yang dinikahi oleh laki-laki yang menghamilinya. Beberapa penafsiran ini menegaskan bahwa nasab anak di luar nikah tersebut tetap pada laki-laki yang menghamili ibunya. $^{42}$

Bersumber dari riwayat dan penafsiran di atas, maka dapat dikatakan bahwa al-walad li al-firäsh menjadi landasan kuat bagi penetapan nasab anak hasil zina kepada bapak biologisnya, bukan pada ibunya sebagaimana yang telah masyhur didengarkan. Lebih jauh, terdapat riwayat Hadìth lain yang memperkuat pandangan ini. Hadīth ini diriwayatkan oleh Muslim, ${ }^{43}$ Bukhārīi, dan lainnya:

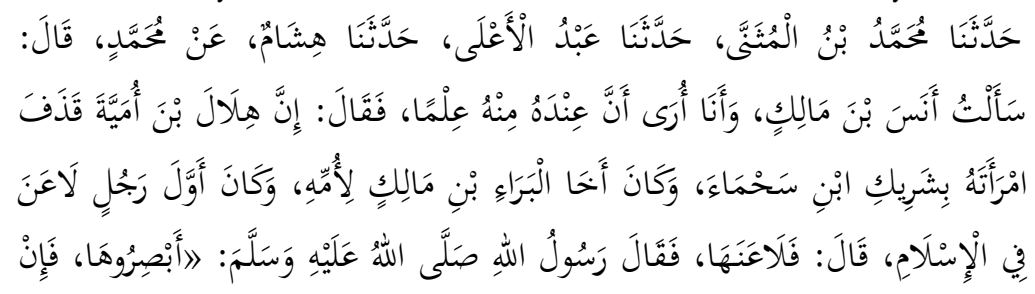

40 Ibn Taymìyah, Majmū' al-Fatāwà, Vol. 7, 420.

41 'Īsā Am'ìzah, "The Legality of the Placement of the Son of Adultery in Islamic Jurisprudence and Algerian Legislation”, al-Ijtihād li Dirāsät al-Q̄ānūnìyah wa al-Iqtisādìyah, Vol. 7, No. 6 (2018), 440.

42 Asriyati, "Hadits al-Walad li al-Firasy sebagai Penetapan Nasab Anak", Diktum: Jurnal Syariah dan Hukum, Vol. 8, No. 2 (2010), 140.

${ }^{43}$ Muslim b. al-Hajjāi al-Naysābūrī, al-Musnad al-Sahīḥ al-Mukbtasar bi Naql al'Adl an al-'Adl ilā Rasūl Allāh, Vol. 2 (Beirut: Dār Ihyā̄' al-Turāth al-'Arabī, t.th.), 1134.

${ }^{44}$ Muḥammad b. Ismā'īl al-Bukhārī, al-Jāmi‘ al-Musnad al-Ṣahīh al-Mukbtasar min Umūr Rusūl Allāh wa Sunanih wa Ayyāmih, Vol. 6 (Beirut: Ṭawq al-Najāh, t.th.), 100. 


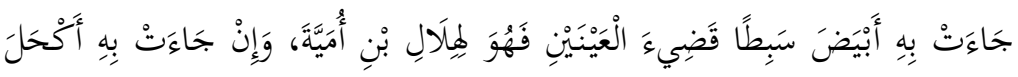

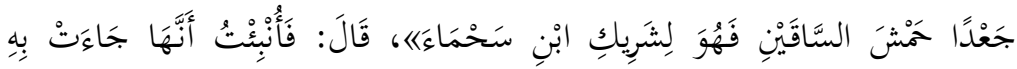

$$
\begin{aligned}
& \text { أَكْحَل جَعْدًا حَمْشَ السَّاقَتْنِ }
\end{aligned}
$$

"Sesungguhnya Hilāl b. Umayyah menuduh istrinya berbuat serong dengan Sharīk b. Saḥmā', yaitu saudara seibu Barrā' b. Mālik, dan laki-laki yang pertama kali melakukan li'àn [sumpah/laknat seorang suami terhadap istri yang dituduh berzina] dalam Islam. Anas berkata: 'Lantas Hilāl melakukan sumpah li'än di hadapan Rasulullah, kemudian beliau bersabda: 'Coba perhatikan perempuan itu, jika nanti anaknya putih, berambut lurus, dan mata agak merah, tandanya bayi tersebut anaknya Hilāl b. Umayyah, tetapi jika matanya agak hitam, rambutnya keriting, dan betisnya ramping, maka bayi tersebut adalah milik Syarīk b. Saḥmā'. Anas berkata: 'Kemudian saya diberitahu orang bahwa anak tersebut bermata hitam, berambut keriting, dan berbetis ramping".

Kisah dalam riwayat ini tidak jauh beda dengan riwayat sebelumnya, yaitu tentang pertikaian kepastian kepemilikan anak. Pada intinya, Nabi Muhammad menetapkan bapak dari anak tersebut dengan konsep adanya kemiripan anak dengan bapaknya. Hikmah yang dapat dipetik dari riwayat ini adalah bahwa anak hasil zina, atau hamil di luar nikah, nasabnya kembali pada bapaknya. Bila dipahami dengan menggunakan mafhüm muwäfaqah, maka tidak mungkin Nabi Muhammad bingung untuk mencari cara dalam menetapkan bapak dari anak tersebut bila akhirnya nasab sang anak kembali pada sang ibu. Oleh karena nasab anak tersebut kembali pada bapaknya, maka metode penetapan nasab yang digunakan nabi adalah adanya kemiripan.

Selain itu, terdapat satu riwayat yang menjelaskan bahwa Nabi Muhammad bercerita pada para sahabat tentang salah seorang dari Ban̄̄ Isrā̄il yang mengalami kasus perzinaan dengan seorang perempuan yang kemudian melahirkan seorang anak. Kisah ini 
dijelaskan oleh para perawi Hadīth seperti Muslim, ${ }^{45}$ Ibn Hibbān, ${ }^{46}$ al-Bayhaqi ${ }^{-47}$ A himad b. Hanbal, ${ }^{48}$ dan lainnya.

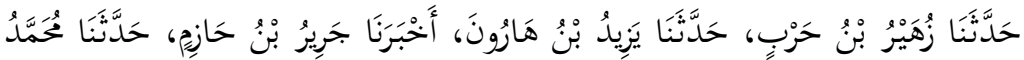

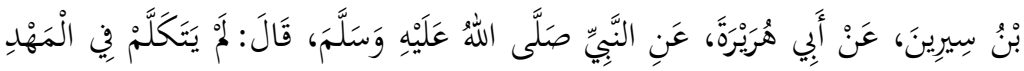

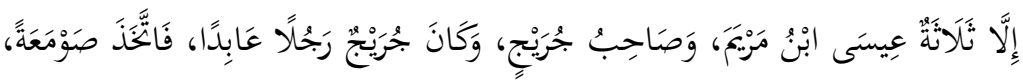

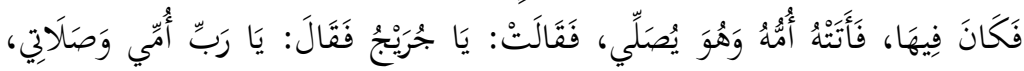

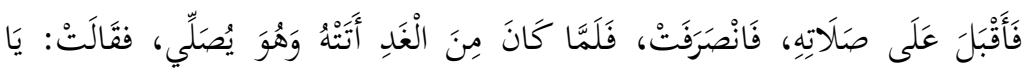

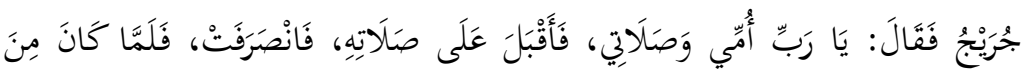

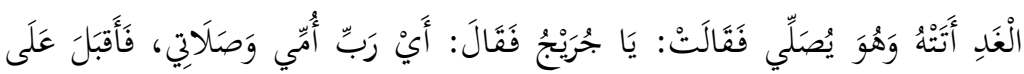

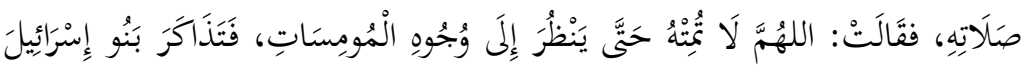

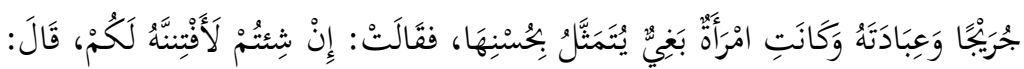

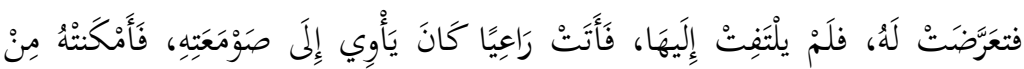

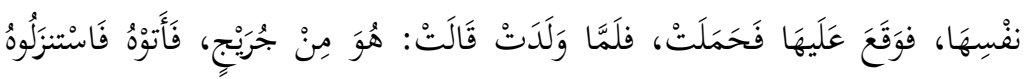

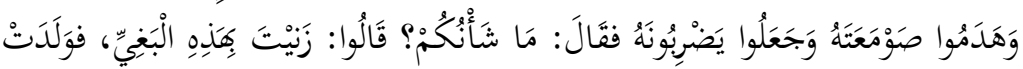

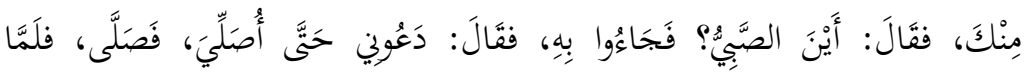

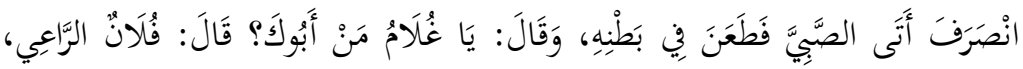

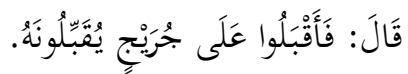

"Dari Abū Hurayrah dari Nabi beliau telah bersabda: 'Tidak ada bayi yang dapat berbicara ketika masih berada dalam buaian kecuali tiga bayi: bayi 'Isā b. Maryam, dan bayi dalam perkara Jurayj'. Jurayj adalah seorang laki-laki ahli ibadah. Ia membangun tempat peribadatan dan senantiasa beribadah di tempat itu. Ketika sedang melaksanakan salat sunnah, tiba-tiba ibunya datang memanggilnya: 'Hai Jurayj!' Jurayj bertanya [dalam hati]; 'Ya Allah, [manakah yang lebih aku utamakan,

\footnotetext{
45 Al-Naysābūrī, al-Musnad al-Sậ̣̄̄, Vol. 4, 1976.

46 Ibn Hibbān, Saḩ̄̄h Ibn Hỉbbān, Vol. 41 (Beirut: Muassasat al-Risālah, 1993), 441.

47 Aḥmad b. al-Ḥusayn al-Bayhaqī, al-Ādāb li al-Bayhaqì, Vol. 1 (Beirut: Muasasat al-Kutub al-Thaqāfiyah, 1988), 309.

48 Ibn Hanbal, Musnad al-Imām Aḥmad, Vol. 1, 434.
} 
melanjutkan] salatku ataukah [memenuhi panggilan] ibuku?' Akhirnya ia meneruskan salatnya dan ibunya pergi. Keesokan harinya, ibunya datang lagi sedangkan Jurayj sedang melakukan salat sunnah. Ibunya memanggil: 'Hai Jurayj!' Jurayj berkata: 'Ya Allah, ibuku ataukah salatku?' Jurayj meneruskan salatnya dan ibunya pergi. Hari berikutnya, ibunya datang lagi ketika Jurayj sedang melaksanakan salat sunnah. Ibunya memanggil: 'Hai Jurayj!' Jurayj berkata: 'Ya Allah, salatku ataukah ibuku?' Jurayj meneruskan salatnya. Kemudian ibunya pun berdoa: 'Ya Allah, janganlah Engkau matikan ia sebelum ia mendapat fitnah dari perempuan pelacur!' Banī Isrā̄il selalu memperbincangkan Jurayj dan ibadahnya, hingga ada seorang wanita pelacur yang cantik berkata: 'Jika kalian mau, aku dapat memfitnahnya demi kalian'. Rasulullah melanjutkan: 'Pelacur itu menggoda Jurayj, tetapi Jurayj tidak tergoda olehnya. Kemudian pelacur itu pergi dan mendatangi seorang penggembala yang berteduh di tempat peribadatan Jurayj. Pelacur tersebut berhasil memperdayai laki-laki penggembala itu, lalu berzina dan hamil. Setelah melahirkan, pelacur itu berkata; 'Ini bayi Jurayj'. Masyarakat pun mendatangi rumah peribadatan Jurayj, menghancurkannya dan menghakimi Jurayj. Jurayj bertanya: 'Apa mau kalian?' Mereka menjawab; 'kamu telah berbuat zina dengan pelacur ini hingga ia melahirkan bayi hasil perbuatanmu'. Jurayj berseru: 'Di manakah bayi itu? Bawa padaku'. Mereka menghadirkan bayi itu, lalu Jurayj menyentuh perutnya dengan jari tangannya seraya bertanya: 'Hai bayi, siapakah ayahmu?' Sang bayi menjawab: 'Si fulan, seorang pengembala'. Rasulullah bersabda: 'Mereka pun menaruh hormat kepada Jurayj dan menciuminya".

Pada riwayat di atas, Nabi menceritakan kasus yang terjadi pada Banī Isrā̄îl, di mana anak zina tetap dinasabkan kepada bapak biologisnya. Hal tersebut dibenarkan oleh Nabi, dengan tidak menyalahkan keputusan Jurayj yang menasabkan anak zina pada bapak biologisnya. Sikap Nabi yang tidak menyalahkan penasaban dalam kasus ini menandakan benarnya keputusan yang ada. Dalam terminologi ilmu hadīth, sikap Nabi yang tidak menyalahkan dalam sebuah kejadian disebut dengan taqrìr al-Rasül.

Kedua, Athar. Kasus anak zina yang nasabnya ditetapkan kepada bapaknya, bukan kepada ibunya, pernah terjadi pada masa 'Umar 
b. al-Khattāb. Al-Khattāb menetapkan sebuah hukum bahwa anak yang dilahirkan dari hasil perzinaan maka nasabnya ditetapkan kepada bapaknya. Penetapan nasab sebagaimana yang diputuskan al-Khattāa ini telah diriwayatkan oleh sekian banyak ulama fiqh, hadìth, dan tafsir. Riwayat tersebut adalah berikut:

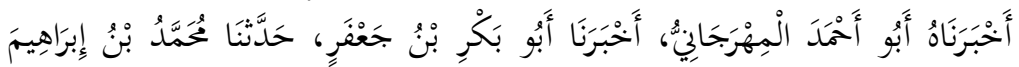

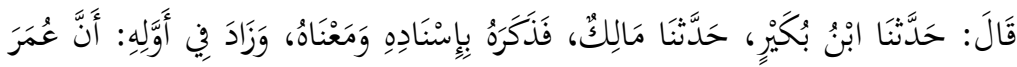

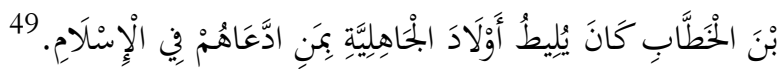

" "Umar b. al-Khattāb dahulu menasabkan anak-anak jahiliyah kepada yang mengakuinya (sebagai anak) dalam Islam".

Al-Khattāb merupakan salah seorang sahabat Nabi yang sangat berhati-hati dalam memutuskan sebuah persoalan yang terjadi. Dalam kasus lahirnya anak hasil zina, al-Khattāb memutuskan bahwa anak tersebut tetap bernasabkan kepada bapak biologisnya. Jika keputusan al-Khațtāb mengenai kasus ini salah, pasti para sahabat menyalahkan keputusannya tersebut. Namun, pada kenyataannya, tidak ada satupun sahabat yang menyalahkan putusan al-Khațtāb. Dengan demikian, maka nasab anak yang lahir dari perzinaan bernasabkan kepada bapak biologisnya.

Ketiga, logika. Bila ditinjau dari sudut pandang logika, seorang wanita tidak akan bisa hamil atau melahirkan tanpa adanya sperma laki-laki (kecuali kasus Nabi Adam dan Nabi 'Īsā). Dengan masuknya sperma dan membuahi sel telur dalam rahim perempuan, tidak ada perbedaan antara orang yang menikah secara sah dengan orang yang melakukan seks di luar nikah. Dengan demikian, maka sangat tidak konsisten ketika menghukumi nasab bayi yang terlahir dengan ikatan pernikahan dan yang lahir di luar itu dengan hukum yang berbeda, sebab bayi tidak akan terlahir tanpa adanya sperma laki-laki. Oleh karena itu, tidak salah bila Muḥammad b. Șālih al-'Uthaymin menjelaskan "ketika seorang perempuan hamil disebabkan zina, maka tidak ada keraguan anak

\footnotetext{
${ }^{49}$ Al-Bayhaqī, Ma'rifah al-Sunan wa al-Āthār, Vol. 14, 373; lihat juga Anas b. Mālik al-Madanī, al-Muwatța', Vol. 4 (Emirat: Muasasat Zayd b. Sultān Al-Nahyān, 2004), 1072; Al-Mubārak b. Muḥammad Ibn al-Athīr al-Jazarī, Jāmi‘ al-Ușūl fì Aḥädìth al-Rasūl, Vol. 10 (Beirut: Dār al-Fikr, 1972), 737; Ibn 'Abd al-Bar Yūsuf b. 'Abd Allāh b. Muḥammad, al-Istidhkearr, Vol. 7 (Beirut: Dār al-Kutub al'Ilmīyah, 2000), 171.
} 
itu tercipta dari sperma laki-laki yang menzinainya. Nasab dari anak itu tetap pada laki-laki yang menzinainya, meskipun zina bukanlah cara yang tepat untuk melanjutkan persambungan nasab". ${ }^{50}$ Dari pernyataan al-'Uthaymin ini tampak bahwa anak zina tetap bernasabkan pada bapaknya, walau pada dasarnya tidaklah tepat mendapatkan seorang anak dengan jalan perzinaan, karena hal tersebut dilarang dalam Islam.

Jika direnungkan kembali, tidak ada satupun manusia yang ingin terlahir dengan cara perzinaan. Kenyataan bahwa seseorang yang terlahir dengan cara yang tidak dibenarkan oleh sharî́ah tentu bukanlah kehendaknya sendiri dan bukan pula ia yang melakukan kesalahan tersebut. Dengan demikian, sangat tidak relevan bila kesalahan dua orang yang berzina "dilimpahkan" kepada bayi yang tidak tahu-menahu tentang perzinaan tersebut. Al-Qur'ān sendiri telah menyinggung bahwa tidak ada satupun orang yang dapat menanggung kesalahan orang lain, kecuali orang yang melakukan itu sendiri.

Di antara ayat al-Qur'ān yang menjelaskan tentang persoalan ini adalah Fātir [35]: 18, yang bunyi ayatnya adalah sebagai berikut:

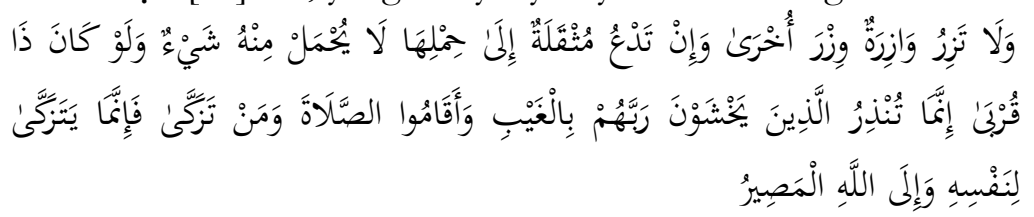

"Dan orang yang berdosa tidak akan memikul dosa orang lain. Dan jika seseorang yang berat dosanya memanggil (orang lain) untuk memikul dosanya itu tiadalah akan dipikulkan untuknya sedikitpun meskipun (yang dipanggilnya itu) kaum kerabatnya. Sesungguhnya yang dapat kamu beri peringatan hanya orangorang yang takut kepada azab Tuhannya (sekalipun) mereka tidak melihat-Nya dan mereka mendirikan sembahyang. Dan barangsiapa yang menyucikan dirinya, sesungguhnya ia menyucikan diri untuk kebaikan dirinya sendiri. Dan kepada Allahlah kembali-(mu)". ${ }^{51}$

\footnotetext{
${ }^{50}$ Muhammad b. Ṣalih al-'Uthaymin, Sharḥ Rìyạd al-Săliḩ̣in, Vol. 2 (Riyadh: Dār al-Wațn li al-Nashr, 1426), 44.

${ }^{51}$ Departemen Agama Republik Indonesia, Al-Qur'an dan Terjemabnya (Bandung: CV Diponegoro, 2008), 436.
} 
Mengenai ayat ini, Muḥammad Maḥmūd al-Hijāzī menafsirkan "tidak mungkin seseorang menanggung beban dosa orang lain, sehingga dosa orang lain hilang dari pemilik dosanya. Ayat ini diturunkan untuk memberikan jawaban terhadap orang-orang yang berkata, 'kami tidak akan disiksa. Jika memang ada siksaan, maka yang akan disiksa adalah nenek moyang kami, sebab kami mengikuti mereka". ${ }^{2}$ Demikian juga dengan penafsiran Ibn Kathīr, "ayat ini menjelaskan bahwa kesalahan seseorang tidak akan dapat dibebankan pada orang lain. Hal ini sebagai bukti sifat adilnya Allah". ${ }^{3}$

Ayat di atas berikut penafsiran ulama terhadapnya menjadi landasan kuat bahwa bayi yang terlahir sebagai hasil zina tidak dapat menjadi pelampiasan dosa atau kesalahan kedua orang tuanya yang berzina. Kesalahan dan dosa hanya berlaku pada dua orang yang berzina saja. Jika demikian, maka sangat tidak etis efek kesalahan orang berzina mengakibatkan putusnya hubungan nasab anak hasil zina pada bapak biologisnya. Oleh karena itu, tidak salah bila Samad dan Rab memberikan kesimpulan bahwa seorang anak tidak ikut campur masalah dosa yang dilakukan kedua orang tuanya. Meniadakan nasab seorang anak pada bapaknya lebih memberikan mudarat pada anak yang bersangkutan dari pada menetapkan nasab pada bapaknya. ${ }^{54}$

Salah satu tokoh maqāsid al-sharíah juga menjelaskan mengenai nasab anak hasil zina:

Adanya anak tanpa adanya bapak dalam kehidupan sosial bukanlah tujuan dari sharīah, sebab hal ini dapat berefek samping rusaknya kejiwaan dan pikiran. Lebih parah dari itu, adanya anak tanpa bapak dapat merusak pada tatanan kehidupan sosial. Jalan satu-satunya untuk mencegah kerusakan sosial ini adalah pengakuan nasab anak hasil zina pada bapaknya, bukan pada ibunya. Hal ini demi mendapatkan kemaslahatan, sehingga tidak akan ditemukan anak terlahir tanpa adanya nasab. .55

\footnotetext{
52 Muḥammad Maḥmūd al-Ḥijāzī, al-Tafsìr al-Wädịh, Vol. 2 (Beirut: Dār al-Jayl alJadīiah, 1413), 360.

${ }^{53}$ Ismā'îl b. 'Umar b. Kathīr, Tafsìr al-Qur'ān al-'Az̧̄ìm, Vol. 3 (Beirut: Dār alKutub al-'Ilmìyah, 1419), 345.

${ }^{54}$ Samad dan al-Quibaty, Nasb Wald al-Zinā, 131.

55 Aḥmad al-Raysūnī, Nažrìah al-Taqrìb wa al-Taghlìb wa Tatbiqā̇uh fì al-'Ulūm alIslāmìyah (Kairo: Dār al-Kalimah, 2010), 356.
} 
Dari penjelasan di atas, terlihat jelas bahwa anak zina tidak seharusnya mendapatkan beban kesalahan yang telah dilakukan pelaku zina, karena kesalahan itu murni dari kedua orang (tua) yang berzina; dan kesalahan seseorang tidak dapat dibebankan pada orang lain. Dengan demikian, tidak seharusnya anak zina tidak dinasabkan pada bapaknya. Selain itu, adanya keputusan tersebut dapat berdampak buruk pada anak yang bersangkutan, baik dalam kehidupan sosial atau lainnya. Oleh karena itu, menetapkan hubungan nasab anak zina pada bapaknya lebih utama dari pada meniadakannya.

\section{Refleksi terhadap Argumen Nasab Anak Zina pada Ibu}

Setelah melakukan pengkajian terhadap argumen ulama yang menyatakan bahwa anak hasil zina bernasabkan pada ibu (bukan pada bapak biologisnya), penulis tidak menemukan landasan argumen yang bersumber langsung dari ayat-ayat al-Qur'ān maupun Hadìth Nabi. Satu-satunya Hadīth yang dapat dijadikan sandaran adalah al-walad li al-firäsh. Wahbah al-Zuhaylī berpendapat bahwa anak zina bernasabkan pada ibu dengan landasan hadīth tersebut. Kemudian ia menegaskan bahwa "harus diberi sanksi had bagi pelaku zina dan tidak boleh anak hasil zina dinasabkan kepadanya, sebab ketika anak zina dinasabkan kepadanya sama halnya memberika jalan lebar untuk seseorang melakukan perzinaan. Saya lebih memilih untuk mencegah kerusakan dan menjaga kehormatan nasab sehingga tidak tercampur dengan sesuatu yang mungkar". ${ }^{56}$ Senada dengan itu, Maria Ulfah menegaskan, "berkenaan dengan hal ini [penetapan nasab anak zina pada bapaknya], kita pun tidak boleh terpaku pada legalitas hukum sebagian ulama. Upaya penangkalan harus dipikirkan supaya tidak terjadi perbuatan zina". ${ }^{57}$

Samad dan Rab, setelah melakukan kajian terhadap alasan ulama perihal anak hasil zina yang tidak dinasabkan pada bapaknya, menyatakan bahwa hal itu disebabkan ketidaktahuan dalam menentukan apakah anak tersebut hasil dari sperma orang yang mengakuinya atau tidak. ${ }^{58}$ Semua ini disebabkan oleh kenyataan

56 Wahbah Muṣtafā al-Zuhaylī, "Aḥkām al-Awlād al-Nātijīn 'an al-Zinā”, Dawrah al-'Ishrūn li al-Majma' al-Fiqhī al-Islāmī, Mekah (Desember, 2010), 14.

${ }^{57}$ Maria Ulfah, "Wanita Hamil di Luar Nikah (Status Anak)", Jurnal Pembaharuan Hukum, Vol. 2, No. 3 (2015), 333.

${ }^{58}$ Samad dan al-Quibaty, Nasb Walad al-Zinā, 132. 
bahwa pada masa dahulu belum ditemukan alat DNA atau sejenisnya. Oleh karena kekhawatiran anak hasil zina tersebut bukan dari sperma laki-laki yang mangakuinya, maka ulama mengambil kesimpulan anak hasil zina tidak memiliki nasab pada bapaknya. Hal ini berkesesuaian dengan ajaran agama Islam yang sangat menjunjung tinggi pelestarian dan pemuliaan garis keturunan.

Jika alasan anak hasil zina tidak dinasabkan pada bapaknya hanya karena ketidakjelasan dari laki-laki mana sebuah sperma berasal, maka hasil ijtihad ulama tersebut sejatinya dapat diubah dengan adanya teknologi yang mumpuni pada masa sekarang, baik melalui tes DNA atau tes medis lainnya yang dapat membuktikan hubungan darah. Untuk sekadar memastikan hubungan darah, beberapa penelitian menjelaskan bahwa akurasi tes DNA sangat tinggi, bahkan dapat mencapai $100 \%$ jika dilakukan dengan benar. ${ }^{59}$ Terkait ini, Taufik Suryadi berkesimpulan bahwa "analisis DNA untuk mengidentifikasi golongan darah sangat penting dilakukan mengingat ketepatan metode ini mendekati $100 \%$." ${ }^{\circ 0}$ Mengacu terhadap kenyataan tersebut, maka tindakan tes DNA untuk menentukan hubungan darah atau nasab anak hasil zina dapat menjadi langkah perubahan ijtihad para ulama klasik. Hal ini selaras dengan rumusan bahwa hukum bisa saja berubah mengikuti perubahan 'illah-nya, ${ }^{61}$ dan bahwa ijtihad dapat berubah mengikuti perubahan ruang dan waktu yang ada. ${ }^{62}$ Dengan demikian, maka hasil ijtihad tentang nasab anak zina dapat berubah hukumnya.

Argumen tentang menjaga kemurnian dan kehormatan nasab pun dapat terbantahkan. Yang menjadi hilangnya kemurnian dan kehormatan nasab adalah ketidakjelasan sperma laki-laki yang membuat anak zina terlahir. Ketidakjelasan tersebut bisa diakibatkan oleh kenyataan seorang perempuan yang melakukan hubungan seks dengan banyak laki-laki atau terdapat pengakuan dari dua laki-

\footnotetext{
${ }^{59}$ Hapry Lapian, “DNA: Akurat Memastikan Identitas Seseorang”, 26 Juni 2015, https://www.kompasiana.com/haprylapian/550ba4438133115922b1e156/dnaakurat-memastikan-identitas-seseorang.

60 Taufik Suryadi, "Teknik Analisis DNA dalam Mengidentifikasi Genotip Golongan Darah pada Jenazah Kasus Forensik", Jurnal Kedokteran Syiah Kuala, Vol. 15, No. 3 (2015), 161.

${ }^{61}$ Al-Sarakhsī, Ușül al-Sarakhsì, Vol. 2. Beirut: Dār al-Ma'rifah, t.th.

${ }^{62}$ Al-Fāsī, Muhammad b. al-Hasan b. al-'Arabī. Al-Fiker al-Sāmì fì Tārikeh al-Fiqh al-Islämì, Vol. 2 (Beirut: Dār al-Kutub al-'Ilmīyah, 1995), 574.
} 
laki atau lebih, dan terutama hal inilah yang mengakibatkan ketidakjelasan nasab pada masa terdahulu. Namun, problem tersebut kini dapat diurai dengan kecanggihan teknologi yang ada pada masa sekarang. Dengan demikian, ditemukannya bapak biologis anak zina tentu dapat melindungi kemurnian atau kehormatan nasab sebagaimana hal tersebut dijunjung tinggi oleh ajaran agama Islam.

Sementara itu, jika yang menjadi alasan adalah semakin terbukanya pintu seks bebas dan maraknya anak terlahir tanpa status ikatan pernikahan yang sah, maka peneliti dapat mengatakan bahwa yang demikian ini bukan alasan yang tetap, sebab hukum pelaku zina sudah ditetapkan secara jelas baik dalam al-Qur'ān atau Hadīth Nabi Muhammad. Sebagaimana dijelaskan dalam al-Nūr [24]: 2 sebagai berikut:

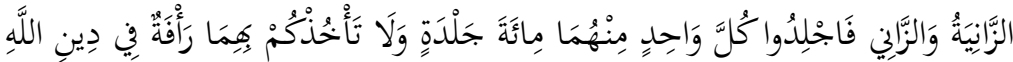

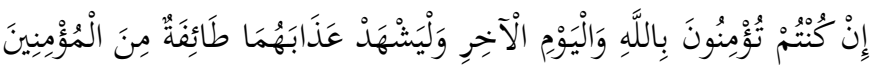

"Perempuan yang berzina dan laki-laki yang berzina, maka deralah tiap-tiap seorang dari keduanya seratus kali dera, dan janganlah belas kasihan kepada keduanya mencegah kamu untuk (menjalankan) agama Allah, jika kamu beriman kepada Allah dan hari akhirat, dan hendaklah (pelaksanaan) hukuman mereka disaksikan oleh sekumpulan orang-orang yang beriman". ${ }^{63}$

Dalam sebuah hadīth juga dijelaskan larangan berzina sebagaimana diriwayatkan oleh al-Bayhaq1 ${ }^{-64}$ dan lainnya:

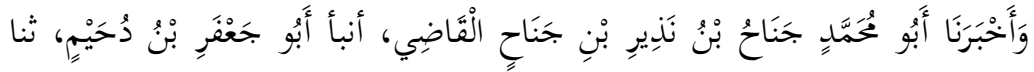

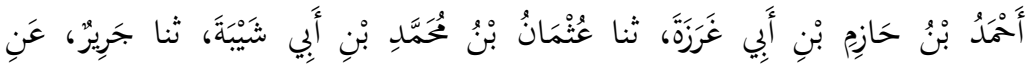

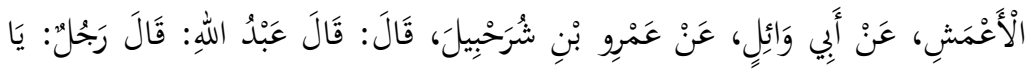

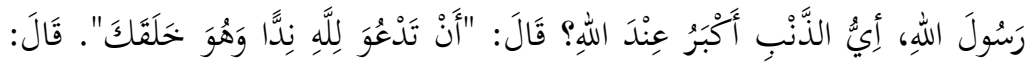

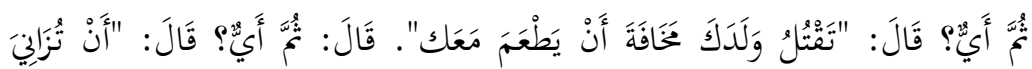
حَلِيلَة جَارِكَ.

\footnotetext{
63 Departemen Agama Republik Indonesia, Al-Qur'an dan Terjemahnya, 350.

${ }^{64}$ Al-Bayhaqī, al-Sunan al-Kubrā, Vol. 8, 27.
} 
“Aku telah bertanya kepada Nabi: 'Dosa apakah yang paling besar?' Ia menjawab: 'Engkau menjadikan tandingan atau sekutu bagi Allah, padahal Allah telah menciptakanmu'. Aku bertanya lagi: 'Kemudian apa?' Ia menjawab: 'Membunuh anakmu karena takut dia akan makan bersamamu'. Aku bertanya lagi: 'Kemudian apa?' Ia menjawab lagi: 'Kamu berzina dengan istri tetanggamu",.

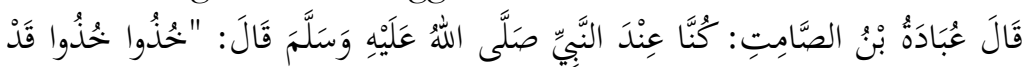

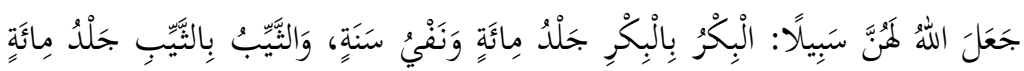

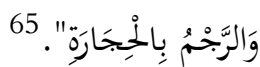

"Ambillah dariku! Ambillah dariku! Sungguh Allah telah menjadikan bagi mereka jalan, yang belum menikah (berzina) dengan orang yang belum menikah, dikenakan seratus dera dan diasingkan setahun"; yang sudah menikah (berzina) dengan yang sudah menikah dikenakan seratus dera dan rajam pakai batu".

Baik redaksi ayat al-Qur'ān maupun Hadìth Nabi Muhammad tersebut telah menjelaskan sanksi bagi pelaku zina baik berupa jild atau rajm. Dengan adanya peraturan ini, maka sanksi bagi pelaku zina sudah sangat jelas, dan tidak seharusnya konsekuensi yang ditimbulkan perbuatan zina tersebut masih berimbas pada tiadanya nasab seorang anak yang dihasilkan dari perzinaan.

\section{Penutup}

Nasab merupakan hal yang sangat urgen dan mendapatkan perhatian penuh dalam agama Islam. Perihal anak hasil zina, ijtihad mayoritas ulama menasabkannya pada ibunya, bukan pada bapak biologisnya, dengan alasan sulitnya menentukan hubungan darah dengan bapak biologisnya, lebih-lebih jika sang ibu berhubungan dengan tidak hanya satu laki-laki dan atau adanya pengakuan yang tidak hanya datang dati satu laki-laki saja. Berdasarkan beberapa pembahasan dalam artikel ini, argumen-argumen mayoritas ulama tersebut sudah saatnya ditinjau ulang; selain tidak ada satupun landasan dari al-Qur'ān dan Hadīth yang menjelaskan bahwa anak tersebut bernasabkan pada ibu, ruang dan waktu juga terus bergeser dan mulai menunjukkan kemajuan signifikan di bidang

${ }^{65}$ Ibid., 366. 
teknologi. Akhirnya, artikel ini secara jelas menyatakan bahwa anak hasil zina tetap bernasab pada bapak biologisnya, sebab seorang anak tidak akan bisa terlahir tanpa adanya sperma laki-laki. Seorang anak yang baru lahir seharusnya tidak tidak ikut 'menangung' kesalahan yang dilakukan oleh kedua orang tuanya yang melakukan hubungan tanpa ikatan pernikahan. Selain itu, sanksi pelaku zina juga sudah dijelaskan dalam al-Qur'ān dan Ḥadìth.

\section{Daftar Rujukan}

Al Amruzi, Fahmi. "Hak dan Status Anak Syubhat dalam Pernikahan", Syariab: Jurnal Hukum dan Pemikiran, Vol. 17, No. 1, 2017.

Am'īzah, 'Īsā. "The Legality of the Placement of the Son of Adultery in Islamic Jurisprudence and Algerian Legislation", alIjtihāed li Dirāsāt al-Qānūnìah wa al-Iqtișädìyah, Vol. 7, No. 6, 2018.

Anșārī (al), Zakariyyā. Asnā al-Matălib fì Sharḥ Rawḍ al-Ṭälib, Vol. 3. Beirūt: Dār al-'Ilmīyah, 2000.

Asriyati. "Hadits al-Walad li al-Firasy sebagai Penetapan Nasab

Anak", Diktum: Jumal Syariah dan Hukum, Vol. 8, No. 2, 2010.

Baghawī (al), al-Husayn b. Mas'ūd. Sharḥ al-Sunnah, Vol. 9. Beirut: al-Maktab al-Islāmī, 1983.

Bayhaqī (al), Aḥmad b. al-Ḥusayn. Al-Ādāb li al-Bayhaqì, Vol. 1. Beirut: Muasasat al-Kutub al-Thaqāfìah, 1988.

-----. Al-Sunan al-Kubrā, Vol. 6 (Beirut: Dār al-Kutub al-'Ilmīyah, 2003.

-----. Ma'rifah al-Sunan wa al-Āthär, Vol. 8. Mesir: Dār al-Wifā', 1991.

Buhādah, Samiyah. "Ishkālāt Ithbāt al-Nasb bi al-Ṭarq al-'Ilmīyah al-Hadīthah (al-Bașmah al-Warāthīyah)", al-Dirāsāt wa al-Bubüth al-Qänünìyah, Vol. 1, No. 1, 2016.

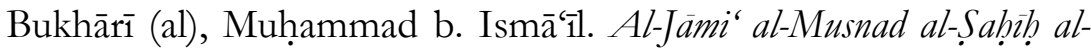
Mukhtasar min Umūr Rusūl Allāh wa Sunanih wa Ayyāmih, Vol. 6. Beirut: Ṭawq al-Najāh, t.th.

Chaq, Moh. Dliya'ul. "Nasab Anak dalam Hukum Islam; Membaca Peluang Sains dan Teknologi dalam Penetapan Nasab", Tafáqqub: Jurnal Penelitian dan Kajian Keislaman, Vol. 6, No. 1, 2018. 
Dawādī, 'Abd al-Qādir. Aḥām al-Usrah bayn al-Fiqh al-Islāmì wa Qānūn al-Usrah al-Jazāìirì. Beirut: Dār al-Bașāìir, 2010.

Departemen Agama Republik Indonesia. Al-Qur'an dan Terjemahnya. Bandung: CV Diponegoro, 2008.

Fāsī (al), Muhạmmad b. al-Ḥasan b. al-'Arabī. Al-Fiker al-Sāmì fi Tärikeh al-Fiqh al-Islāmi, Vol. 2. Beirut: Dār al-Kutub al-'Ilmìyah, 1995.

Fayḍ̄ (al), Awān 'Abd Allāh. "Suit for DNA Correction Comparative Study in Judicial Evidence", Route Education and Social Science, Vol. 5, No. 6, 2018.

Hịāzīi (al), Muhammad Maḥmūd. Al-Tafsìr al-Wädịh, Vol. 2. Beirut: Dār al-Jayl al-Jadīdah, 1413.

Husayn, Aḥmad Farāj. Aḥkām al-Usrah fì al-Islām, al-Talāq wa Huqūq al-Awlād wa Nafaqāt al-Aqārib. Beirut: Dār al-Jāmi'ah li alNashr, 1998.

Ib Hazm, 'Alī b. Muḥammad. Al-Muḥallā, Vol. 9. Beirut: Dār alFikr, t.th.

Ibn Hanbal, Aḥmad b. Muhammad. Musnad al-Imām Aḅmad b. Hanbal, Vol. 41. Beirut: Muassasat al-Risālah, 2001.

Ibn Hibbān. Sahị̣̄. Ibn Hibbān, Vol. 41. Beirut: Muassasat alRisālah, 1993.

Ibn Kathīr, Ismāīil b. 'Umar. Tafsì al-Qur'ān al-'Az̧ìm, Vol. 3. Beirut: Dār al-Kutub al-'Ilmīyah, 1419.

Ibn Mājah, Muḥammad b. Yazīd. Sunan Ibn Mājah, Vol. 3. Beirut: Dār al-Risālah al-'Ālamīyah, 2009.

Ibn Muhạmmad, Ibn 'Abd al-Bar Yūsuf b. 'Abd Allāh. Al-Istidhkearr, Vol. 7. Beirut: Dār al-Kutub al-'Ilmìyah, 2000.

Ibn Qudāmah, 'Abd Allāh b. Aḥmad. Al-Mughnā fì Fiqh al-Imām Aḥmad b. Hanbal, Vol. 7. Beirut: Dār al-Fikr, 1405.

----. Al-Mughnī li Ibn Qudāmah, Vol. 6. Beirut: Dār al-Fikr, 1405.

Ibn Rushd, Muhammad b. Ahmad. Al-Bayān wa al-Tahșil wa alSharḥ wa al-Tawjīh wa al-Ta'lì li Masāil al-Mustakhrajah, Vol. 14. Beirut: Dār al-Gharb al-Islāmī, 1988.

Ibn Taymìyah, Aḥmad b. 'Abd al-Halīm. Al-Fatāwā al-Kubrā, Vol. 3. Beirut: Dār al-Kutub al-'Ilmìyah, 1987. -. Majmū' al-Fatāwā, Vol. 32. Beirut: Dār al-Wifā’, 2005. 
Jawzī (al), Muhammad b. Abī Bakr. Jalā' al-Afhām fì Fadl al-Ṣalāh 'alà Muḥammad Khayr al-Anām, Vol. 1. Beirut: Dār al-Ma'rifah, 1987.

Jazarī (al), al-Mubārak b. Muḥammad Ibn al-Athīr. Jāmi‘ al-Ușūl fì Aḥädith al-Rasūl, Vol. 10. Beirut: Dār al-Fikr, 1972.

Khadījah, La'īi. Al-Turq al-Shariȳah li Ithbät al-Nasb fi al-Fiqh alIslämi wa al-Tashrī al-Jazāiòì. Tesis--Jāmi'ah Muhammad Khayd̦īr, 2015.

Lapian, Hapry. "DNA: Akurat Memastikan Identitas Seseorang", 26 Juni 2015, https://www.kompasiana.com/haprylapian/ 550ba4438133115922b1e156/dna-akurat-memastikanidentitas-seseorang.

Madanī (al), Anas b. Mālik. Al-Muwatța', Vol. 4. Emirat: Muasasat Zayd b. Sultānn al-Nahyān, 2004.

Majelis Ulama Indonesia. Fatwa No. 11 Tahun 2012 tentang Kedudukan Anak Hasil Zina dan Perlakuan Terhadapnya.

Mustaghfir, Agus. "Kewarisan Anak Zina dalam Tinjauan Hukum Islam dan KUH Perdata". Tesis--IAIN Ponorogo, 2018.

Nasā̄ì (al), Aḥmad b. Shu'ayb. al-Sunan al-Kubrā, Vol. 5. Beirūt: Muassasat al-Risālah, 2001.

Nawawī (al), Muhy al-Dīn b. Sharf. Al-Majmū' Sharḥ al-Muhadhdhab, Vol. 15. Beirut: Dār al-Fikr, t.th.

Naysābūrī (al), Muslim b. al-Hajjāj. Al-Musnad al-Sahīḥ al-Mukbtașar bi Naql al-'Adl an al-'Adl ilā Rasūl Alläh, Vol. 2. Beirut: Dār Ihyeā' al-Turāth al-'Arabī, t.th.

Qarāfì (al), Aḥmad b. Idrīs. Al-Furūq, Vol. 4. Mesir: Dār al-Salām, 2001.

Qaswaynī (al), Aḥmad b. Fāris. Mu'jam Maqāyìs al-Lughah, Vol. 4. Beirut: Dār al-Kutub al-'Ilmīyah, 1979.

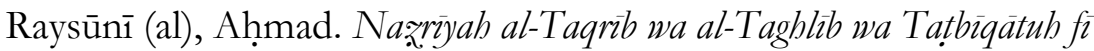
al-'Ulüm al-Islämìyah. Kairo: Dār al-Kalimah, 2010.

Sa'īì̄ (al), 'Abd al-Wahhāb Aḥmad Muhammad. "Ithbāt al-Nasb wa Nafyuh fī al-Islām: Dirāsah fĩ al-Murtakiz al-Uṣūlī wa alMunjiz al-Fiqhì”, Jami'ah al-Nāsr, Vol. 2, No. 4, 2014.

Samad, Doucoure Abdou dan Muneer Ali Abdul Rab al-Quibaty. "Nasb Walad al-Zinā: Dirāsah Fiqhīyah fì Dạ, Maqșud Hif̣ al-Nasl", al-Ulüm al-Islämìyah al-Dawlìyah, Vol. 1, No. 2, 2017. 
Sarakhsī (al), Muḥammad b. Aḥmad b. Abī Sahl. Al-Mabsūt li alSarakhsī, Vol. 8. Beirut: Dār al-Ma'rifah, 1993.

----. Ușül al-Sarkhasì, Vol. 2. Beirut: Dār al-Ma'rifah, t.th.

Sartawī (al), Mạ̣mūd. 'Alī. Figh al-Aḥwäl al-Shakhsizyah (al-Zawäj wa al-Ṭalàq). Beirut: Dār al-Fikr, 2008.

Satiyarti, Rina Budi et al. "Identifikasi Fragmen DNA Mitokondria pada Satu Garis Keturunan Ibu dari Sel Epitel Rongga Mulut dan Sel Folikel Akar Rambut", Biosfer, Vol. 8, No. 1, 2017.

Shalabī, Aḥmad Muṣtafā. Aḥkeàm al-Usrah fì al-Isläm: Dirāsah Muqāranah bayn al-Madhähib al-Sunniyah wa al-Madhäbib alJa'farìyah wa al-Qānūn. Beirut: Dār al-Nahḍah al-'Arabīyah li alNashr, 1977.

Sharbīnī (al), Muḥammad al-Khaṭīb. Mughnì al-Muḅtāj ilā Márifat Ma'àni Alfāà al-Minhāj, Vol. 4. Beirut: Dār al-Fikr, t.th.

Shātibī (al), Ibrāhīm b. Mūsā b. Muhammad. Ușūl al-Fiqh wa alQawāì al-Fiqhìyah, Vol. 4. Beirut: Dār Ibn 'Affān, 1997.

Shawkānī (al), Muḥammad b. 'Alī b. Muhammad. Nayl al-Awtàr min Aḅädith Sayyid al-Akbbār, Vol. 6. Mesir: Idārah al-Ṭaba'ah alMunīīyah, t.th.

Shayrāzī (al), Ibrāhīm b. 'Alī b. Yūsuf. Al-Muhadhdhab fì Fiqh alImām al-Shāfí̀ Vol. 2. Beirut: Dār al-Fikr, t.th.

Suryadi, Taufik. "Teknik Analisis DNA dalam Mengidentifikasi Genotip Golongan Darah pada Jenazah Kasus Forensik", Jurnal Kedokteran Syiah Kuala, Vol. 15, No. 3, 2015.

Ulfah, Maria. "Wanita Hamil di Luar Nikah (Status Anak)", Jurnal Pembaharuan Hukum, Vol. 2, No. 3, 2015.

Utami, Ifititah. "Eksistensi Tes Deoxyribo Nucleic Acid dalam Menentukan Nasab", Medina-Te, Vol. 14, No. 2, 2016.

Uthaymin (al), Muhạmmad b. Șāliḥ. Sharḥ Riyậd al-Ṣälihịn, Vol. 2. Riyadh: Dār al-Waṭn li al-Nashr, 1426.

Zubaydī (al), Muḥammad b. Muḥammad b. 'Abd al-Razzāq. Tāj al'Arūs min Jawāhir al-Qāmùs, Vol. 17. Kuwait: Dār al-Hidāyah, 2004.

Zuhaylī (al), Wahbah Muștafā. "Ahkām al-Awlād al-Nātijīn 'an alZinā”, Dawrah al-'Ishrūn li al-Majma' al-Fiqhī al-Islāmī, Mekah, Desember 2010.

-----. Al-Fiqh al-Islāmi wa Adillatuh, Vol. 7. Beirut: Dār al-Fikr, 1984. 